\title{
Microstructure, physicochemistry, microbial populations and aroma compounds of ripened Cantal cheeses
}

\author{
Isabelle De Freitas a, Nicolas PINON ${ }^{\mathrm{a}}$, Christelle LOPEZ ${ }^{\mathrm{b}}$, Anne ThIERRY, \\ Jean-Louis MAUBOIS ${ }^{\mathrm{*}}$, Sylvie LORTAL ${ }^{\mathrm{b}}$ \\ ${ }^{a}$ Les Fromageries Occitanes (LFO), Borde Blanche - Zone Industrielle, \\ 31290 Villefranche de Lauragais, France \\ b UMR 1253, Science et Technologie du Lait et de l'CEuf, Inra-Agrocampus Rennes, \\ 65 rue de Saint Brieuc, 35042 Rennes Cedex, France
}

Received 10 March 2005 - Accepted 13 April 2005

Published online 1 October 2005

\begin{abstract}
In spite of its high production (18000 T yearly), very few studies have been devoted to Cantal, a French AOC ("Appellation d'Origine Contrôlée") cheese variety whose making process is close to that of Cheddar. To improve the knowledge of this type of cheese, two ripened Cantal cheeses issued from raw milk and two different industrial processes were biochemically, physicochemically, structurally and microbiologically characterised through the analysis of both cheese sectors and juices extracted by pressure. The results obtained were compared with Cheddar and Emmental cheeses. The main differences between Cheddar and Cantal cheeses of the same age were a higher rate of proteolysis for Cantal cheese shown by both the total nitrogen content and the TCA soluble nitrogen in the respective cheese juices, and higher $\mathrm{Ca}_{\mathrm{T}}$ content as well as an increased molar $\mathrm{Ca}_{\mathrm{T}} / \mathrm{P}_{\mathrm{T}}$ ratio in the Cantal cheese. Free amino contents in the cheese aqueous phase were similar but individual variations suggested an effect of the secondary ripening microflora provided by the raw milk used. Microbial counts done on different media showed a dominant mesophilic and thermophilic lactic acid bacteria flora, a subdominant flora composed of various ripening bacteria and yeasts and a very low level of some coliforms and of Pseudomonas. An amount of 44 neutral volatile compounds were identified but 3 of them determined by GC-MS (ethanol, 2-butanone and 2-butanol) represented more than $95 \%$ of the total peak area. Some variations in these main compounds as well as in minor ones confirmed a difference in the native microflora in the two studied Cantal cheeses. Nevertheless, these data appeared in the range of those reported for Cheddar. The microstructure of fat determined by confocal laser scanning micrography showed that little is present in Cantal cheese as intact fat globules. Most of this component appeared as free fat included in the casein matrix with a high ability to oil off, especially the part which is near the crust. As well as offering a precise characterisation of many compositional aspects of ripened Cantal cheese, this study opens the way for further works on the process kinetics carried out in the making processes and for a better knowledge of the ecosystem metabolism.
\end{abstract}

Cantal cheese / composition / ripening / proteolysis / mineral composition / microbial flora / neutral volatile compound / fat microstructure

\footnotetext{
* Corresponding author (通讯作者): jean-louis.maubois@ rennes.inra.fr
} 
摘要 - 成熟的法国硬干酷微观结构、理化特性、微生物菌群和芳香化合物。法国硬干酪 (Cantal Cheese) 是一种法国原产地控制命名 (AOC) 干酪的变种，其生产工艺类似于契达干酪 (Cheddar Cheese)。尽管法国硬干酪的年产量可达 $18000 \mathrm{t}$, 但是对这种干酪的研究还很少。为 了深入了解法国硬干酪的特性，本文选择 2 个由不同生产工艺生产的成熟的法国硬干酪作 为研究样品, 该干酪均是以未经巴氏杀菌的牛乳为原料生产。通过分析干酪和干酪榨出液, 系统地研究了该干酪的生物化学、物理化学、结构和微生物特性。并将测定结果与契达干 酪和埃门塔尔干酪 (Emmental Cheeses) 进行比较。试验结果表明, 相同成熟时间的法国硬干 酪和契达干酪的主要差异是法国硬干酪的蛋白水解率较高, 所以檫出液中总氮和 TCA 可溶 性氮的含量较高, 同样在法国硬干酪中总钲 $\left(\mathrm{Ca}_{\mathrm{T}}\right)$ 含量和总钻与总磷 $\left(\mathrm{Ca}_{\mathrm{T}} / \mathrm{P}_{\mathrm{T}}\right)$ 摩尔比较高。 干酪液相中的游离氨基酸含量相近, 但是其中个别氨基酸含量有所差异, 这可能是由于原 料乳的次级成熟微生物不同，使干酪成熟过程中发生了不同的变化而造成的。将法国硬干 酪在不同的培养基和培养条件下培养, 结果表明, 样品中优势菌群是嗜温乳酸菌和嗜热乳 酸菌, 其次是一些成熟细菌和酵母, 以及少量的大肠菌群和假单胞菌属。在法国硬干酪中 共鉴定出 44 种中性挥发性化合物, 采用气相色谱一质谱 (GC-MS) 法分析结果表明其中 3 种 化合物 (乙醇、2-丁酮、2-丁醇) 的峰面积之和占总峰面积的 $95 \%$ 以上。在所研究的 2 个法国硬干酪中，主要化合物以及一些微量化合物的差异都是由于其自身的微生物区系不 同而造成的。但是在法国硬干酪中测得的关于挥发性成分的相关数据都接近契达干酪文献 报道的数据。采用共焦激光扫描显微镜测定了脂肪的微观结构, 可以观察到法国硬干酪中 只有少量的脂肪球是完整的。大多数脂肪以游离的形式存在于酪蛋白基质中, 这种酪蛋白 基质具有较强的析油能力, 尤其是接近干酪硬表皮的部分这种析油现象更突出。本文还对 成熟的法国硬干酪许多成分特性进行了深入的阐述, 为进一步研究加工动力学和生态代谢 奠定了基础。

法国硬干酪 / 组成 / 成熟 / 蛋白水解 / 矿物质组成 / 微生物菌群 / 中性挥发性化合物 / 脂肪的 微观结构

Résumé - Microstructure, physico-chimie, flore microbienne et composés aromatiques du fromage de Cantal affiné. En dépit de sa production élevée (18000 T/an), peu d'études ont été consacrées au Cantal ( $3^{e}$ Appellation d'Origine Contrôlée française) dont le procédé de fabrication peut être rapproché de celui du Cheddar. Pour accroître les connaissances sur cette variété de fromage, deux fromages Cantal affinés, obtenus à partir de lait cru, selon deux procédés de fabrication ont été caractérisés analytiquement au plan biochimique, physico-chimique, microbiologique et microstructural, à la fois par l'analyse des fromages et de leurs jus respectifs obtenus par extraction sous pression. Les résultats obtenus ont été comparés aux données existantes sur le Cheddar et l'Emmental. Les principales différences mises en évidence entre Cantal et Cheddar concernent le niveau de protéolyse (teneurs en $\mathrm{N} \times 6,38$ et proportion de $\mathrm{N}$ soluble dans le TCA accrues par rapport aux jus extraits de Cheddar), une teneur en $\mathrm{Ca}_{\mathrm{T}}$ ainsi qu'un rapport molaire $\mathrm{Ca}_{\mathrm{T}} / \mathrm{P}_{\mathrm{T}}$ plus élevés dans le Cantal. Si la teneur en acides aminés libres ne différait globalement pas de celle décrite pour le Cheddar, les variations déterminées au niveau individuel suggéraient que l'activité métabolique de la microflore d'affinage (probablement apportée par le lait cru mis en œuvre) était différente entre les deux Cantal étudiés. Les déterminations microbiologiques effectuées à l'aide de différents milieux de culture montraient que la flore était principalement constituée de bactéries lactiques mésophiles et thermophiles. Toutefois, une microflore d'affinage très variée (probablement, propionibacteria, corynebacteria, staphylocoques et microcoques ainsi que des levures), à des niveaux de $10^{4}$ à $10^{5} \mathrm{ufc} \cdot \mathrm{g}^{-1} \mathrm{a}$ pu être identifiée et comparée aux quelques données existantes de la littérature. Une très faible teneur en bactéries indésirables (coliformes et Pseudomonas) a également été dénombrée. Un total de 44 composés volatils neutres ont été caractérisés mais comme pour de nombreuses autres variétés fromagères incluant le Cheddar, trois d'entre eux (éthanol, 2-butanone et 2-butanol) représentent plus de $95 \%$ de l'aire totale des pics déterminés par chromatographie gazeuse couplée à la spectrométrie de masse. La comparaison détaillée des teneurs en composés volatils des deux Cantal étudiés confirmaient la différence d'activité métabolique de la microflore native des laits mis respectivement en fabrication. L'analyse de la microstructure des fromages par microscopie confocale à laser, montrait que l'essentiel de la matière grasse du Cantal se trouvait sous forme non structurée en globules mais bien sous forme d'amas de taille variable ayant une propension aisée à s'extraire de la matrice caséique, et ce particulièrement pour la matière grasse voisine de la croûte du fromage. Les résultats obtenus précisent sur de nombreux aspects les paramètres de composition du Cantal affiné. Ils ouvrent également la voie à de nouveaux travaux tant sur les cinétiques d'obtention 
mises en œuvre au cours du procédé de fabrication de ces paramètres que sur une meilleure connaissance du métabolisme de l'écosystème d'acidification et d'affinage.

fromage / Cantal / composition / affinage / composition minérale / protéolyse / flore microbienne / composé volatil neutre / microstructure / matière grasse

\section{INTRODUCTION}

Cantal cheese is the third most produced AOC ("Appellation d'origine Contrôlée") cheese variety in France with a yearly production of $18000 \mathrm{~T}$ [13]. It is made from either raw or pasteurised milk and commercialised as "young" (ripened for at least 30 days), "between the two" (ripened for 2 to 6 months) or "old" (ripened for over 6 months). Two other AOC cheeses, made from raw milk only, "Laguiole" and "Salers", belong to the same cheese family produced in the central area of France, with a respective annual production of $700 \mathrm{~T}$ and $1400 \mathrm{~T}$ [12]. These cheeses are commercialised as 35- to 40-kg, 40-cm height, 36to $42-\mathrm{cm}$ diameter round wheels with a dry crust. The Total Solids (TS) content and the Fat/TS ratio must be, respectively, at least $57 \%$ and 0.45 [54]. In some aspects, Cantal cheesemaking can be compared with that of Cheddar, whose ancestor it would be, according to Pline the Old. Indeed, the renneted curd is cut, drained and pressed to form a "tome" in which lactic acidification will take place. Then, the acidified "tome" is milled, salted, moulded and pressed before ripening.

Surprisingly, very little literature has been devoted to the characterisation of this cheese variety. Most of the studies are related to the microbial ecosystem involved in the transformation of raw milk in Cantal. Millet et al. [52] have enumerated the microbial flora of 31 two- to five-month aged cheese samples. In spite of the relatively small number of cheese samples, they were able to correlate high counts in Lactobacillus brevis, coliforms, Micrococcus, Staphylococcus and yeasts with unpleasant tasting cheeses. By using modern molecular identification methods on 381 strains, Callon et al. [11] have confirmed the diversity of the lactic acid bacteria present in the AOC parent cheese variety "Salers" and equally identified more accurately the different species of Leuconostoc and mesophilic Lactobacillus. From a combination of single strand conformation polymorphism (SSCP) analysis and clone library sequencing, Duthoit et al. [21] were able to follow the dynamics of these numerous lactic acid bacteria during manufacture and ripening of 3 Salers cheeses. They also showed the presence of a high-GC\% Grampositive group (essentially corynebacteria) in the inner part of this cheese variety. Millet et al. [53], from a study on 38 yeast strains (characterised as belonging to the species Torulopsis sphaerica, Saccharomyces lactis and $S$. fragilis) isolated from Cantal tome, indicated that $53 \%$ of them were able to ferment lactose, and consequently they hypothesised that yeasts play two actions in the process: to prevent the undesirable blowing of cheese in the press step and to contribute by their $\mathrm{CO}_{2}$ production to the requested texture of the cheese.

Some studies have shown the effects of the cow's feeding on the organoleptic quality of Cantal cheese. Cheese made from raw milks with a high terpene content obtained either by feeding with the spignel plant (Meum athamanticum) or by direct addition of essential oil led to Cantal cheeses with significant i) higher "flower" flavour and ii) more elastic texture than the control because of a small increase in the rate of proteolysis [46] which could be an effect of terpene on the metabolism of some specific microorganisms. On the other hand, VerdierMetz et al. [65] concluded that pasteurisation of milk modified much more sensory properties of cheese than the cow's diet.

In order to partly fill this lack of knowledge, the aim of this study was to characterise diverse aspects: physicochemistry, microbiology, rheology and microstructure, of two commercial Cantal cheese samples issued from two different manufacturing processes. 


\section{MATERIALS AND METHODS}

\subsection{Cheese samples}

Some cheeses (A) issued from a highly industrial process using widely mixed raw milk. Other cheeses (B) also issued from raw milk but according to a small-scale process without mechanisation. Both processes included addition of lactic starters. Ripening conditions were the same $\left(10^{\circ} \mathrm{C}\right.$, $95 \%$ relative humidity). Samples of around $5.0 \mathrm{~kg}$ each were analysed after 4 months of ripening (129 d (A) and $131 \mathrm{~d}(\mathbf{B}))$.

\subsection{Extraction of the cheese aqueous phase (juice) and lipidic phase}

The cheese aqueous and lipidic phases were extracted according to the procedure of Salvat-Brunaud et al. [59]. The outer part of the cheese samples ( $2 \mathrm{~cm}$ under the crust) was removed and a sector of $1800 \mathrm{~g}$ was grated and thoroughly mixed with two parts $(3600 \mathrm{~g})$ of Fontainebleau sand (VWR, Strasbourg, France), then packed into a perforated (Perfora type 5, APV Baker, Evreux, France) stainless steel mould which was lined with a disposable cheese cloth (Smith and Nephew Extruded Films, Ltd, Hull, UK). The mould filled with the cheese-sand mixture was then placed on the stainless steel press plate (Mecalef Industrie, Rennes, France) and pressed at $16^{\circ} \mathrm{C}-18^{\circ} \mathrm{C}$ using an electric hydraulic press (Trans Hydro, Morlaix, France). Pressure was increased gradually firstly from 0 to 37 bars in 110 min and secondly from 37 to 45 bars in $70 \mathrm{~min}$. The expressed liquids were collected in a graduated cylinder with an opening at the bottom which allowed the separate collection in bottles of both aqueous and lipidic phases. The extracted phases were centrifuged for $6 \mathrm{~min}$ at $900 \mathrm{rpm}$ at room temperature (Kunke Gerber Super Quattro, Grosseron, St Herblain, France) to remove solid particles and analysed either immediately or after storage at $-20{ }^{\circ} \mathrm{C}$ or $-60{ }^{\circ} \mathrm{C}$.

\subsection{Physicochemical analysis}

For these determinations, the outer part of the cheese samples ( $2 \mathrm{~cm}$ under the crust) were removed and a sector of about $150 \mathrm{~g}$ was grated and thoroughly homogenised and then used.

- $\mathrm{pH}$ was measured by a $\mathrm{pH}-$ meter (HI 9025, Hanna Instruments, Vila do Conde, Portugal);

- total solids (TS) were determined by drying both cheese ( $2 \mathrm{~g}$ ) and juice ( $5 \mathrm{~g})$ samples mixed with sand at $102{ }^{\circ} \mathrm{C}$ for $7 \mathrm{~h}$ [22];

- fat was determined by the SchmidBondzynski-Ratzlaff (SBR) method [24];

- nitrogen contents were determined by the macro-Kjeldhal method [26] with 6.38 as the conversion factor; total nitrogen matter (TNM) in cheese and the aqueous phase was measured directly; non-casein nitrogen $(\mathrm{NCN})$ was measured at $\mathrm{pH} 4.4$ for cheese and at $\mathrm{pH} 4.6$ for juice; non-protein nitrogen (NPN) was measured in $12 \%$ TCA (trichloroacetic acid). Soluble nitrogen after precipitation with phosphotungstic acid (NSPA) was determined according to Kuchroo and Fox [40];

- free amino acid contents were determined after deproteinisation of samples by sulfosalicylic acid according to the method described by Saboya et al. [58];

- ash contents were determined by incineration of $5 \mathrm{~g}$ of the aqueous phase or $2 \mathrm{~g}$ of cheese in a oven at $550^{\circ} \mathrm{C}$ for $5 \mathrm{~h}$ [2];

- determination of cations (calcium, magnesium, potassium and sodium) were realised from ashes dissolved in $\mathrm{HCl}$ ( $1 \mathrm{~mol} \cdot \mathrm{L}^{-1}$ solution) followed by atomic absorption spectrometry (SpectrAA 220 FS, Varian, Palo Alto, CA, USA), according to Brulé et al. [10].

- anions (lactate, propionate, butyrate, chlorides, nitrate, succinate, carbonate, sulphate, inorganic phosphate and citrate) were determined by ionic chromatography (DX500 Dionex Corporation, Sunnyvale, CA, USA) with an IonPac AS11 column (4 $\times$ $250 \mathrm{~mm}$ ) [31];

- Total phosphorus was determined by the colorimetric method [23]. A conversion factor of 95/31 was used to convert the $\mathrm{P}$ content into phosphate concentration. 
Each determination was done in triplicate, and the average and standard deviation (SD) were calculated.

\subsection{Peptidic profile}

HPLC chromatography (Waters 2790, Waters, Milford, MA, USA) allowed the separation of individual peptidic components. Reverse phase separation on a C18 column - $2.1 \mathrm{~mm}$ diameter, $150 \mathrm{~mm}$ length (Symmetry, Waters) - was achieved using (A) $1.06 \%$ trifluoroacetic acid (TFA) in water, and (B) 1\%o TFA in acetonitrile/ water $(80 / 20, v / v)$ as eluents. Separation was obtained in $98 \mathrm{~min}$ on the column, with a flow rate of $0.25 \mathrm{~mL} \cdot \mathrm{min}^{-1}$ and eluent $\mathrm{B}$ increasing from 2 to $60 \%$ in $77 \mathrm{~min}$. Sample preparation involve NCN solution diluted in water $(200 \mu \mathrm{L}$ in $500 \mu \mathrm{L}) ; 40 \mu \mathrm{L}$ of this dilution were mixed with $80 \mu \mathrm{L}$ of $8 \mathrm{~mol} \cdot \mathrm{L}^{-1}$ urea and $880 \mu \mathrm{L}$ of $2 \%$ o TFA.

\subsection{Volatile compounds}

Neutral volatile compounds were extracted and identified by dynamic headspace analysis (Tekmar 3000, Tekmar Inc., Cincinnati, OH, USA) coupled to gas chromatography (HP5890A, Hewlett Packard, Avondale, PA, USA) and mass spectrometry (HP 7972A quadrupole mass spectrometer) from 7-g cheese samples, 4-g juice samples and 6.2-g extracted oil samples, according to Thierry et al. [61]. Peaks were quantified by the areas of the total ion current (TIC). Ethanol content was determined by the enzymatic method through the use of Boehringer kits.

\subsection{Microbiology}

Cheese samples were prepared as described by Saboya et al. [58]. The inner parts of cheeses were aseptically sampled $(10 \mathrm{~g})$. To differentiate the microflora, various growth media were used (time and temperature of incubation are reported in Tab. IV). When anaerobic conditions were required, Petri dishes were incubated in anaerobic jars containing "Anaerocult ${ }^{\circledR}$ " gas packs (Merck, Nogent-sur-Marne, France). Mean values resulted from duplicate plates.
- Mesophilic aerobic and psychrotrophic microflora: plate count agar (PCA, Biokar Diagnostics, Beauvais, France) [1];

- lactococci and thermophilic streptococci: medium 17 (M17, Difco laboratories, Detroit, MI, USA) with lactose (10\%, Merck) [28];

- mesophilic and thermophilic lactobacilli: de Man, Rogosa and Sharpe pH 5.4 (MRS, Difco), anaerobic incubation (Anaerocult, Merck) [28];

- facultatively heterofermentative lactobacilli: FH agar [37];

- coryneform bacteria: cheese ripening bacteria medium (CRBM, [19]) with two antibiotic solutions: natamycine $\left(9 \mathrm{mg} \cdot \mathrm{L}^{-1}\right)$ and nalidixic acid (40 $\left.\mathrm{mg} \cdot \mathrm{L}^{-1}\right)$ for the elimination of the fungal flora, Gram-negative bacteria and Bacillus. Only coloured colonies were enumerated on this medium;

- propionibacteria: Lithium-GlycerolAgar (LGA) with Pal Propiobac ${ }^{\circledR}$ antibiotic supplement (Standa industrie, Caen, France) [44];

- enterococci: KF Streptococcus agar (Biokar) [27];

- coliforms: violet red bile agar (VRBA, Difco) [3];

-E. coli: Tryptone Bile X-glucuronide Agar (TBX, Biokar) [36];

- Staphylococci: Baird Parker (AES, Combourg, France) [4];

- Pseudomonas: Pseudomonas-CFC (AES) [48];

- yeasts: Oxytetracycline Glucose Agar (OGA, Biokar) [25].

In order to identify the possible presence of thermophilic flora, six colonies were picked up randomly on M17 agar plates incubated at $43{ }^{\circ} \mathrm{C}$, propagated in M17 medium $24 \mathrm{~h}$ at $37^{\circ} \mathrm{C}$ and further characterised (morphology and fermentation pattern) by using API 20 Strep strips (Biomérieux, Lyon, France).

\subsection{Microstructure}

Fat microstructure in Cantal cheese B was examined using confocal laser scanning 
Table I. Physicochemical data of cheese and juice of two Cantal cheeses (A, B); comparison with $\mathrm{Cheddar}^{1}$ and Emmental ${ }^{2,3}$. Numbers in brackets express contents in $1000 \mathrm{~g}$ of water. Values are mean of two (pH, TNM, NCN, NPN, NSPA, ash) or three (TS, fat) determinations.

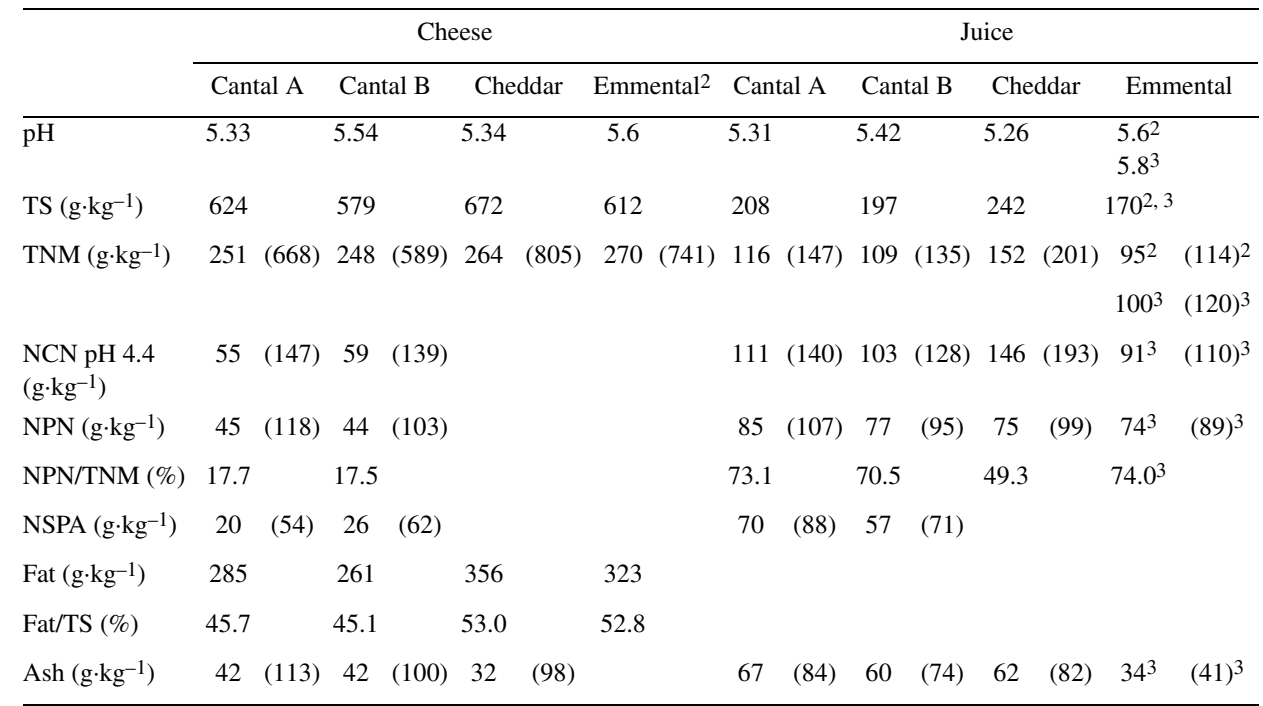

$1[57]$

$2[42]$

3 Series A from Thierry et al. [62].

microscopy (CLSM). Thin slices $(5 \times 5$ $\mathrm{mm})$ of approximately 3-mm thickness were cut from the samples with a scalpel. The protein network was stained using Acridine Orange fluorescent dye (Aldrich Chemical Company, Inc., Milwaukee, USA). A lipid-soluble Nile Red fluorescent dye (Sigma - Aldrich, St Louis, USA) was used for colouring fat. Each slice was placed between a microscope slide and a cover slip. The cheese slices were then incubated with the stains for $30 \mathrm{~min}$ in the dark at $4{ }^{\circ} \mathrm{C}$. Microstructural analysis was done using a confocal Leica TCS NT microscope (Leica, microsystems, Heidelberg, Germany), with the use of an argon/krypton laser in dual-beam fluorescent mode, with excitation wavelengths of $568 \mathrm{~nm}$ and 488 $\mathrm{nm}$ for, respectively, fat and protein. The $2 \mathrm{D}$ images had a resolution of $1024 \times 1024$ pixels and the pixel scale values were converted into micrometers using a scaling factor. In the doubled stained samples, the fat phase was red and the protein phase was coloured in greyscale.

\section{RESULTS AND DISCUSSION}

\subsection{Physicochemical composition}

\subsubsection{Main physicochemical characteristics}

The average compositions of both varieties of Cantal cheeses and their aqueous phases are summarised in Table I which also indicates the data obtained, respectively, by Salvat-Brunaud et al. [59] on 3month-old Emmental cheese and Roy et al. [57] on 6-month-old Cheddar cheese, made from $1.4-\mu \mathrm{m}$ microfiltrated milk. For an easier comparison between the three cheese varieties, composition of soluble components is expressed for $1000 \mathrm{~g}$ of cheese or juice water. Both series of Cantal cheese were in the usual range of composition [65]. B Cantal cheeses had higher $\mathrm{pH}$ and moisture contents than A Cantal cheeses. TS content of cheese juices was approximately threefold the usual TS content of cheese 
Table II. Ion composition of two Cantal cheeses (A, B); comparison with Cheddar $^{1}$ and Emmental $^{2}$. Number in brackets express contents in $1000 \mathrm{~g}$ of water. Values are mean of two determinations.

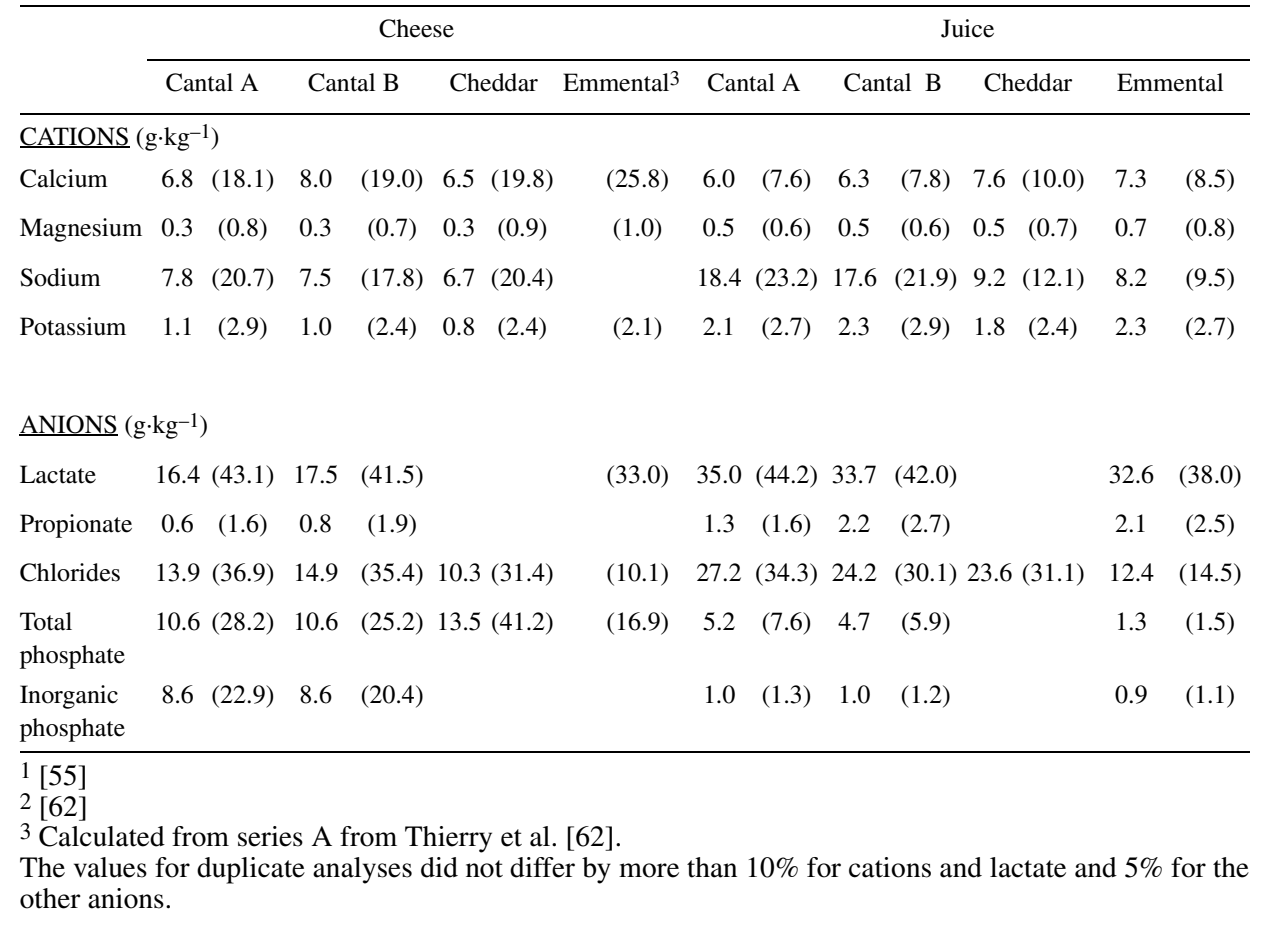

whey because of salt addition and proteolysis of the casein network. The proteolysis indices, calculated as the percentage of cheese TNM present in the cheese juice were, respectively, $22.0 \%, 22.9 \%, 25.0 \%$ and $15.4 \%$ for Cantal $\mathrm{A}$ and B, Cheddar and Emmental. More than $70 \%$ of the cheese juice TNM was TCA soluble for Cantal and Emmental cheeses with only $50 \%$ for Cheddar. The intensity and nature of solubilised casein fragments in the cheese juice appeared to be interesting data for distinguishing Cantal from Cheddar, which are produced according to similar technologies, both using mesophilic starters but different ripening temperatures. There were no differences in ash contents between Cheddar and Cantal but both had almost twice more than Emmental.

In Table II average cation and anion contents determined on cheeses and on their respective juices are summarised. Total calcium content appeared to be greatly different in the two Cantal cheeses but the soluble Ca content in both juices was similar (7.6 and $7.8 \mathrm{~g}$ per $1000 \mathrm{~g}$ of water). From the data of Tables I and II, it can be calculated that the ratio $\mathrm{Ca}_{\mathrm{S}} / \mathrm{Ca}_{\mathrm{T}}$ (values expressed per $1000 \mathrm{~g}$ of water) which is established in the ripened cheese, by (i) the couple kinetics of curd acidification - kinetics of curd drainage, (ii) the salting of the curd and (iii) the caseino-phosphopeptide solubilisation from the cheese matrix during ripening [33], reaches $42 \%$ in Cantal A, $41 \%$ in Cantal B, $42 \%$ and $50.4 \%$ in Cheddar according, respectively, to Hassan et al. [33] and Roy et al. [57] and only 33\% in Emmental [62]. The molar $\mathrm{Ca}_{\mathrm{T}} / \mathrm{P}_{\mathrm{T}}$ ratio in Cantal cheeses A and B are, respectively, 1.5 and 1.8 versus 1.2 in Cheddar and 1.07 in Emmental [42]. In the juices, these molar $\mathrm{Ca}_{\mathrm{T}} / \mathrm{P}_{\mathrm{T}}$ ratios are, respectively, equal to 2.8 


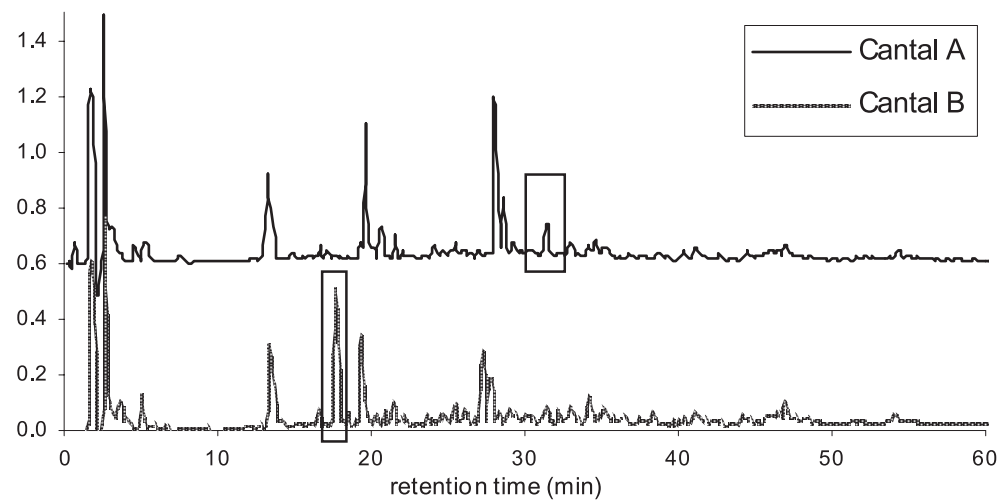

Figure 1. Profiles of peptides obtained by RP-HPLC with the NCN filtrates from the cheese juices.

(Cantal A) and 3.1 (Cantal B). As inorganic phosphate represented only $20 \%$ of the juice phosphate, it is likely that the main part of this mineral was bound to solubilised CPP (caseinophosphopeptides) as suggested by Gagnaire et al. [30] and Hassan et al. [33]. There is no good relationship between $\mathrm{Na}$ content determined in Cantal cheeses ( 7.8 and $\left.7.5 \mathrm{~g} \cdot \mathrm{kg}^{-1}\right)$ and the value calculated from juices (8.7 and $9.2 \mathrm{~g} \cdot \mathrm{kg}^{-1}$ ) but the observed difference is much less than in the same comparison made from the results of Roy et al. [57] for Cheddar: $6.1 \mathrm{~g} \cdot \mathrm{kg}^{-1}$ in the direct determination in cheese and $4.0 \mathrm{~g} \cdot \mathrm{kg}^{-1}$ for the calculation from juice. As said by Mermet [49], it is likely that the cheese matrix induces more inaccuracy in the ICP (Inductively Coupled Plasma) analytical method used by Roy et al. [57] than in the AAS (Atomic Absorption Spectrometry) method used in this study. The molar ratio $(\mathrm{Na}+\mathrm{K}) / \mathrm{Cl}$ in the Cantal cheeses and juices was close to 1 as it was in Cheddar (Tab. II).

\subsubsection{Survey of proteolysis}

Moreover, the repartition between nitrogen distribution in cheeses, and proteolysis in Cantal cheese was also estimated by both the peptidic profiles of juices (Fig. 1) and the free amino acid content (Tab. III). In the first approach, peptidic profiles of both rip- ened cheeses appeared quite similar. However, the relative area of peaks eluted at the same retention time was variable and some peptides were only noticed in one sample (boxed in). Further work is required to characterise by mass spectrometry the different peptides in order to associate them with both endogenous milk enzymes activity and microorganism metabolism as done by Gagnaire et al. [30] on Emmental cheese.

Free amino acid distribution in the cheese juices is given in Table III. Total contents characterised from Cantal A and B (respectively, $32.5 \mathrm{~g} \cdot \mathrm{kg}^{-1}$ and $29.9 \mathrm{~g} \cdot \mathrm{kg}^{-1}$ ) were in the same range as the values determined on Cheddar [57] and on Emmental [59] cheeses with similar ripening duration. It was close to $40 \%$ of the related juice NPN content for both Cantal cheeses. PSer data are also in the same range as those observed by Roy et al. [57] for Cheddar, allowing us to hypothesise that caseinophosphopeptides released in juices from the curd matrix were partially hydrolysed up to $10 \mathrm{mmol} \cdot \mathrm{L}^{-1}$ of free PSer per $\mathrm{kg}$ of juice. However, as shown by De Noni et al. [18] determination of PSer is unreliable and consequently, the aforementioned hypothesis requires confirmation by another analytical measurement of the nitrogen content of cheese juices. Contrarily to Emmental [59] ripened Cantal cheeses, like Cheddar [57], contain free Arg. Contents in free Arg and its derivatives 
Table III. Free amino acids in Cantal cheeses $\mathrm{A}$ and $\mathrm{B}$ and in their respective juices. Values are mean of two determinations.

\begin{tabular}{|c|c|c|c|c|}
\hline & \multicolumn{2}{|c|}{ Cheese } & \multicolumn{2}{|c|}{ Juice } \\
\hline & Cantal A & Cantal B & Cantal A & Cantal B \\
\hline PSer & 0.67 & 0.65 & 1.76 & 1.43 \\
\hline Asp & 0.67 & 0.41 & 1.47 & 0.64 \\
\hline Thr & 0.35 & 0.40 & 0.74 & 0.66 \\
\hline Ser & 0.06 & 0.03 & 0.28 & 0.06 \\
\hline Asn & 1.05 & 1.38 & 2.13 & 2.47 \\
\hline Glu & 2.78 & 3.44 & 6.79 & 6.00 \\
\hline Gln & 0.63 & 0.75 & 1.26 & 1.43 \\
\hline Gly & 0.07 & 0.42 & 0.19 & 0.70 \\
\hline Ala & 0.35 & 0.39 & 0.72 & 0.65 \\
\hline Cit & 0.16 & 0.11 & 0.55 & 0.36 \\
\hline Val & 1.10 & 1.29 & 2.16 & 2.10 \\
\hline Cys & nd & nd & 0.02 & 0.04 \\
\hline Met & 0.45 & 0.44 & 0.83 & 0.67 \\
\hline Cysth & 0.00 & 0.06 & 0.08 & 0.15 \\
\hline Ile & 0.80 & 1.12 & 1.63 & 1.60 \\
\hline Leu & 2.71 & 2.93 & 4.41 & 4.29 \\
\hline Tyr & 0.31 & 0.13 & 0.53 & 0.26 \\
\hline Phe & 1.35 & 1.40 & 2.02 & 1.91 \\
\hline Aaiba & nd & nd & 0.20 & 0.30 \\
\hline Gaba & 0.27 & 0.22 & 0.54 & 0.54 \\
\hline Hylys & 0.16 & 0.12 & 0.45 & 0.20 \\
\hline Orn & 0.47 & 0.13 & 1.00 & 0.20 \\
\hline Lys & 0.85 & 1.14 & 1.99 & 1.77 \\
\hline His & 0.16 & 0.15 & 0.35 & 0.22 \\
\hline $\operatorname{Trp}$ & nd & nd & 0.06 & 0.04 \\
\hline Arg & 0.06 & nd & 0.23 & 0.13 \\
\hline Pro & 0.04 & 0.70 & 0.12 & 1.12 \\
\hline TOTAL & 15.54 & 17.79 & 32.53 & 29.91 \\
\hline
\end{tabular}

PSer: phosphoserine.

Cysth: cystothionine.

Aaiba: $\alpha$-amino-isobutyric acid.

Gaba: $\gamma$-amino-butyric acid.

Hylys: hydroxylysine.

(Orn and Cit) were much higher in the juice of the cheese A than in the juice of the cheese B. Such data suggested as proposed by Curtin and McSweeney [17] that there was a different development of secondary microflora in A and B cheeses, which was not the propionic flora as shown by Laht et al. [41] and by our own results (Tab. IV). That hypothesis is also supported by the very great difference in free Pro (more than ninefold) between the two juices.

\subsection{Microbiology}

Table IV provides the results of microbial counts on the different media incubated under several temperature-time conditions. Both ripened cheese samples shared the following characteristics : (i) a dominant flora composed of various lactic acid bacteria: facultatively heterofermentative lactobacilli at over $10^{7} \mathrm{cfu} \cdot \mathrm{g}^{-1}$, presumptive lactococci at about $10^{7} \mathrm{cfu} \cdot \mathrm{g}^{-1}$, presumptive $S$. thermophilus at about $10^{6} \mathrm{cfu} \cdot \mathrm{g}^{-1}$, thermophilic lactobacilli and enterococci at about $5.10^{5} \mathrm{cfu} \cdot \mathrm{g}^{-1}$, (ii) a subdominant flora composed of various ripening bacteria: presumptive propionibacteria, corynebacteria and staphylococci/micrococci, all at the level of $10^{4}$ to $10^{5} \mathrm{cfu} \cdot \mathrm{g}^{-1}$ (iii) $10^{3}-10^{4} \mathrm{cfu} \cdot \mathrm{g}^{-1}$ yeasts, and (iv) undesirable flora (coliforms, E. coli and Pseudomonas) present at low levels (about $10^{2} \mathrm{cfu} \cdot \mathrm{g}^{-1}$ ).

Our results confirm the large microbial diversity of Cantal cheeses made from raw milk and they are in agreement with the enumeration of Cantal flora done by Millet et al. [52] on 31 two-to five-month aged cheese samples. Like them, we found that the dominant group was composed of facultatively heterofermentative lactobacilli, as observed in many other ripened cheese varieties [6]. Comparison with the existing literature on Cheddar showed that similar counts of starter and non-starter lactic acid bacteria (about $5.10^{7} \mathrm{cfu} \cdot \mathrm{g}^{-1}$ and from $4.10^{7} \mathrm{cfu} \cdot \mathrm{g}^{-1}$ to $9.10^{7} \mathrm{cfu} \cdot \mathrm{g}^{-1}$, respectively, $[29,60])$ were found in Cantal cheese. Many presumptive Lactococcus lactis (not confirmed by specific identification) were enumerated on M17 agar but, as demonstrated by Callon et al. [11], this medium is not very selective. Indeed, lactococci constituted only $20 \%$ of the colonies grown on M17 agar incubated at $30{ }^{\circ} \mathrm{C}$ from samples of ripened Salers cheese. Besides that lactococci flora, Callon et al. [11] have identified a large diversity of other lactic populations 
Table IV. Microbial populations of two Cantal cheeses.

\begin{tabular}{|c|c|c|c|c|}
\hline Medium-temperature-atmosphere & $\begin{array}{l}\text { Incubation } \\
\text { time (days) }\end{array}$ & Targeted population & $\left(\mathrm{cfu} \cdot \mathrm{g}^{-1}\right)$ & $\begin{array}{l}\text { Cantal B } \\
\left.\mathrm{g}^{-1}\right)\end{array}$ \\
\hline PCA $-30{ }^{\circ} \mathrm{C}$ - aerobic & 3 & Total mesophilic counts & $1.0 \times 10^{8}$ & $4.3 \times 10^{7}$ \\
\hline $\mathrm{FH}-37{ }^{\circ} \mathrm{C}$ - anaerobic & 3 & Facultative heterofermentative $\mathrm{lb}$. & $5.5 \times 10^{7}$ & $1.0 \times 10^{7}$ \\
\hline MRS pH $5.4-15^{\circ} \mathrm{C}$ - anaerobic & 10 & Mesophilic lactobacilli & $9.0 \times 10^{6}$ & $1.3 \times 10^{7}$ \\
\hline M17+lactose $-15^{\circ} \mathrm{C}$ - aerobic & 7 & Lactococci & $2.6 \times 10^{6}$ & $2.5 \times 10^{7}$ \\
\hline M17+lactose $-43^{\circ} \mathrm{C}$ - aerobic & 1 & Streptococcus thermophilus & $3.3 \times 10^{6}$ & $1.3 \times 10^{6}$ \\
\hline MRS pH $5.4-43^{\circ} \mathrm{C}$ - anaerobic & 2 & Thermophilic lactobacilli & $1.4 \times 10^{6}$ & $5.3 \times 10^{5}$ \\
\hline $\mathrm{KF}-37^{\circ} \mathrm{C}$ - aerobic & 2 & Enterococci & $4.7 \times 10^{5}$ & $1.1 \times 10^{6}$ \\
\hline $\mathrm{CRBM}-25^{\circ} \mathrm{C} /$ ambient $\mathrm{T}^{\circ}$ - aerobic & $5-15$ & Corynebacteria & $2.4 \times 10^{4}$ & $1.1 \times 10^{5}$ \\
\hline LGA $-30^{\circ} \mathrm{C}$ - anaerobic & 7 & Propionibacteria & $1.5 \times 10^{4}$ & $1.3 \times 10^{4}$ \\
\hline Baird-Parker $-37^{\circ} \mathrm{C}$ - aerobic & 2 & Staphylococcus aureus & nd & nd \\
\hline VRBA $-30{ }^{\circ} \mathrm{C}$ - aerobic & 1 & Total coliforms & $1.6 \times 10^{2}$ & $<10^{2}$ \\
\hline $\mathrm{TBX}-43^{\circ} \mathrm{C}$ - aerobic & 1 & Escherichia coli & $1.4 \times 10^{2}$ & $<10$ \\
\hline Pseudo-CFC - $24{ }^{\circ} \mathrm{C}$ - aerobic & 3 & Pseudomonas & $1.3 \times 10^{2}$ & $<10^{2}$ \\
\hline OGA $-24^{\circ} \mathrm{C}$ - aerobic & 7 & Yeasts & $5.2 \times 10^{3}$ & $7.8 \times 10^{3}$ \\
\hline
\end{tabular}

Nd: not detected.

(lactobacilli, leuconostocs and enterococci) on M17 agar plates incubated at $42{ }^{\circ} \mathrm{C}$ but no $S$. thermophilus. Among the six colonies randomly picked up on the same medium incubated at the same temperature, we were able, through the use of API 20 Strep strips, to identify four as $S$. thermophilus, the other two being identified as Enterococcus faecalis and $E$. durans. Such a result confirmed that, in the studied Cantal cheeses, S. thermophilus was the dominant species growing on this medium. Propionibacterium and Corynebacterium were not checked in Millet et al.'s [52] study but their presence was evidenced in Salers cheese by Duthoit et al. [21] using the SCCP technique. Yeast counts were very close in both Cantal cheeses of the present study $\left(10^{3} \mathrm{cfu} \cdot \mathrm{g}^{-1}\right)$, whereas they varied from $10^{2}$ to $10^{8} \mathrm{cfu} \cdot \mathrm{g}^{-1}$ in the samples of Millet et al. [52]. The possible role of yeasts which may prevent undesirable blowing defects during pressing was underlined by Millet et al. [53]. Coliform and E. coli counts were much less in Cantal cheeses A and B than in the cheeses analysed by Millet et al. [52] $\left(<10^{2} \mathrm{cfu} \cdot \mathrm{g}^{-1}\right.$ versus $10^{3}$ to $\left.10^{7} \mathrm{cfu} \cdot \mathrm{g}^{-1}\right)$. No typical colonies of $S$. aureus (circular, smooth, grey to jet-black black colonies surrounded by an outer clear zone) were observed on Baird-Parker agar. Microorganisms forming atypical colonies on this medium were evidenced at a level of $10^{4} \mathrm{cfu} \cdot \mathrm{g}^{-1}$. They most probably constituted other species of staphylococci, as shown by Devoyod and Millet in Cantal cheese [20] but could also belong to various genera, including Micrococcus spp., Bacillus spp. or Corynebacterium spp., which are able to grow on this medium [66].

\subsection{Volatile compounds}

Table V gathers the forty-four neutral volatile compounds identified in the ripened Cantal cheeses, using either whole cheese, juice or oil samples. Whatever the sample type, the patterns were very close as they were in Emmental [61]. Three compounds: ethanol, 2-butanone and 2-butanol, represented about $96 \%$ and $99 \%$ of the total peak area in, respectively, oil and juice. Detection of high boiling point aldehydes 
Table V. Neutral volatile compounds identified in two Cantal cheeses (A and B).

\begin{tabular}{|c|c|c|c|c|c|}
\hline Detected in & $\mathrm{RT}^{\mathrm{a}}$ & Compound (arbitrary units) b & $A^{c}$ & $\mathrm{~B}^{\mathrm{c}}$ & $\operatorname{Ref}^{\mathrm{d}}$ \\
\hline \multirow[t]{35}{*}{ Juice samples } & $\begin{array}{l}3.18 \\
5.02\end{array}$ & $\begin{array}{l}\text { acetaldehyde } \\
\text { 2-propanone (acetone) }\end{array}$ & $\begin{array}{l}27.4 \\
68.6\end{array}$ & $\begin{array}{c}2.5 \\
17.7\end{array}$ & $\begin{array}{c}\mathbf{C h}_{1,2,3} \\
\mathbf{C h}_{2,3}\end{array}$ \\
\hline & 5.43 & ethanol & 4345.1 & 9079.1 & $\mathbf{C h}^{1,2,3}$ \\
\hline & 7.54 & 1-propanol & nd & 50.2 & $\mathbf{C h}^{1,2,3}$ \\
\hline & 8.42 & 2-butanone & 10032.1 & 5658.7 & $\mathbf{C h}^{1,2,3}$ \\
\hline & 9.60 & 2-butanol & 6823.7 & 15800.0 & $\mathrm{Ch}^{1,2}$ \\
\hline & 10.21 & 2-methyl-1-propanol & 2.0 & 16.4 & $\mathbf{C h}^{1,2,3}$ \\
\hline & 11.24 & 1-butanol & 57.3 & 50.0 & $\mathrm{Ch}^{1,2}$ \\
\hline & 11.98 & 2-pentanone & 38.1 & 11.4 & $\mathbf{C h}^{1,2,3}$ \\
\hline & 12.56 & 2-pentanol & 7.6 & 25.9 & $\mathrm{Ch}^{1,2}$ \\
\hline & 14.08 & 3-methyl-1-butanol & 46.1 & 16.9 & $\mathrm{Ch}^{1,2}$ \\
\hline & 14.23 & 2-methyl-1-butanol & 9.7 & 4.9 & $\mathrm{Ch}^{2}$ \\
\hline & 14.47 & disulfide dimethyl & 2.4 & 8.2 & $\mathrm{Ch}^{1,2} \mathbf{o}^{3}$ \\
\hline & 14.84 & 3-methyl-2-pentanone & 0.7 & nd & $\mathbf{o}^{3}$ \\
\hline & 15.04 & 1-methypropyl acetate & 0.9 & 6.7 & $\mathrm{Ch}^{1}$ \\
\hline & 15.42 & 1-pentanol & 2.8 & 5.1 & $\mathbf{C h}^{1,2,3}$ \\
\hline & 16.35 & 2-hexanone & 0.9 & nd & $\mathrm{Ch}^{2,4}$ \\
\hline & 16.71 & ethyl butanoate & 41.0 & 53.5 & $\mathbf{C h}^{1,2,3} \mathbf{o}^{3}$ \\
\hline & 19.55 & 1-hexanol & 2.8 & 3.4 & $\mathrm{Ch}^{1,2}$ \\
\hline & 19.80 & xylene & 3.4 & 1.0 & $\mathrm{o}^{1}$ \\
\hline & 20.47 & 2-heptanone & 4.1 & 2.1 & $\mathrm{Ch}^{1,2} \mathbf{o}^{3}$ \\
\hline & 20.84 & 2-heptanol & nd & 3.9 & $\mathrm{Ch}^{1} \mathbf{o}^{3}$ \\
\hline & 20.90 & heptanal & 3.9 & 2.8 & $\mathbf{C h}^{1,3}$ \\
\hline & 23.11 & camphene* & 1.0 & 0.4 & $\mathrm{Ch}^{1}$ \\
\hline & 23.39 & 1-heptanol & 25.5 & 13.9 & $\mathrm{Ch}^{1}$ \\
\hline & 23.82 & 1-octen-3-ol* & 8.1 & 0.6 & $\mathbf{o}^{1,3}$ \\
\hline & 24.11 & 6-methyl-5-hepten-2-one $*$ & 0.5 & 0.5 & $\mathrm{o}^{1}$ \\
\hline & 24.25 & 2-octanone & 0.8 & 0.6 & $\mathrm{Ch}^{1}$ \\
\hline & 24.44 & ethyl hexanoate & 1.0 & 1.3 & $\mathbf{C h}^{1,2,3} \mathbf{o}^{3}$ \\
\hline & 24.71 & octanal & 9.4 & 5.9 & $\mathrm{Ch}^{4,5}$ \\
\hline & 25.55 & 2-ethyl-1-hexanol* & 6.0 & 2.1 & $\mathrm{o}^{1}$ \\
\hline & 26.89 & 1-octanol & 10.2 & 4.2 & $\mathrm{Ch}^{1}$ \\
\hline & 27.56 & 2-nonanone & 6.1 & 2.8 & $\mathrm{Ch}^{1,2} \mathbf{o}^{3}$ \\
\hline & 27.90 & nonanal* & 14.3 & 8.6 & $\mathrm{Ch}^{3} \mathbf{o}^{3}$ \\
\hline & 29.78 & 2-decanone & 2.9 & 1.6 & $\mathrm{o}^{1}$ \\
\hline & 30.04 & decanal & 2.3 & 1.4 & $\mathrm{Ch}^{1}$ \\
\hline \multirow[t]{8}{*}{ Oil samples only } & 5.46 & dimethyl sulfide & 19.7 & nd & $\mathbf{C h}^{1,2,3}$ \\
\hline & 10.72 & 3-methylbutanal & 6.7 & 1.6 & $\mathrm{Ch}^{3} \mathrm{o}^{3}$ \\
\hline & 13.15 & n-propyl acetate & 11.2 & 5.9 & $\mathrm{o}^{1}$ \\
\hline & 16.57 & octene* & 2.1 & 6.8 & $\mathrm{o}^{1}$ \\
\hline & 22.24 & 2-methylpropyl butanoate & 1.6 & nd & $\mathrm{o}^{1}$ \\
\hline & 22.48 & alpha pinene & 3.7 & 1.3 & $\mathbf{C h}^{3,4}$ \\
\hline & 28.47 & 2-methylpropyl hexanoate* & 0.7 & 0.6 & $\mathrm{o}^{1}$ \\
\hline & 29.79 & ethyl octanoate & 2.6 & 1.0 & $\mathbf{C h}^{3} \mathbf{o}^{3}$ \\
\hline
\end{tabular}

${ }^{\mathrm{a}} \mathrm{RT}$, retention time in GC-MS. ${ }^{\mathrm{b}}$ Compounds marked with * were tentatively identified by comparison of mass spectral data with those of the NIST $75 \mathrm{~K}$ database. ${ }^{c}$ Results are means of two determinations. ${ }^{d}$ Bibliographical references in Cheddar cheese $(\mathrm{Ch})$ or in other cheeses $(0)$ : ${ }^{1}[43]{ }^{2}[63]^{3}[16]{ }^{4}[8]{ }^{5}[64]$. In bold: odour-active compound in Cheddar cheese [16]. 
and ketones was improved in juice samples, whereas esters and hydrocarbons were only found in oil and cheese samples. Alcohols (15 compounds) were quantitatively the main chemical class in the headspace of both Cantal cheeses, which showed great similarities. The other identified compounds belonged to various chemical families: ten ketones, six aldehydes, seven esters, two sulphur compounds and four hydrocarbons. Previously published data on Cantal cheese volatiles being lacking, comparison was made with the results described for Cheddar with the use of the same methodology [43]. Ethanol, which represented 20 and $29 \%$ (based on peak areas) of total volatiles of, respectively, juices $\mathrm{A}$ and $\mathrm{B}$, was also determined by the enzymic method. The contents in Cantal cheese A and its juice were, respectively, $0.03 \mathrm{~g} \cdot \mathrm{kg}^{-1}$ and $0.08 \mathrm{~g} \cdot \mathrm{kg}^{-1}$ versus $0.085 \mathrm{~g} \cdot \mathrm{kg}^{-1}$ and $0.14 \mathrm{~g} \cdot \mathrm{kg}^{-1}$ for Cantal cheese B and its juice. Such contents are in the large range of values determined for Cheddar cheese but higher than the values of Emmental cheese $[7,43,45]$. They appear significantly different but as shown in Table IV, there is no correlation with the population of enumerated living yeasts which is the same in both Cantal cheese series. Either yeast growth was different during the time course of the cheeses ageing or the nature of the yeast species was different as shown recently by Arfi et al. [5] in a Camembert cheese model. Another explanation of the difference seen could also be a different production of this metabolic compound by heterofermentative bacteria such as Leuconostoc or even homofermentative lactic acid bacteria such as Lactococci and thermophilic Lactobacilli [14, 34, 35]. Ethanol, like other alcohols, is thought to have little direct impact on cheese flavour but it may contribute through its ability to form esters with free fatty acids such as ethyl butanoate and ethyl hexanoate characterised here and considered as flavouractive compounds in Cheddar [16]. 2-butanol and 2-butanone accounted for, respectively, $78 \%$ and $70 \%$ of total volatiles of juices $A$ and $\mathrm{B}$ on the basis of peak areas. These compounds, which were also reported in large amounts in Cheddar cheese headspace
$[7,8,67]$, derived from the reduction of 2,3 butanedione (diacetyl) [63]. Neither diacetyl nor its reduced products, acetoine and 2,3butanediol, which resulted from citrate metabolism by mesophilic starters, were detected in ripened Cantal cheeses. Degradation of diacetyl in Cantal cheese during ripening appears similar to or even higher than that observed in Cheddar cheese [7]. Conversion of 2,3-butanediol into 2butanone and subsequently into the reduced 2-butanol was attributed to some nonstarter Lactobacillus species [39, 47]. The concentration of 2-butanone in Cantal cheese $\mathrm{A}$ is much higher than in Cantal cheese $\mathrm{B}$, whereas the concentration of 2butanol is higher in Cantal cheese B than in Cantal cheese A. A similar pattern was observed for other methyl-ketones and secondary alcohols, such as 2-pentanone/2pentanol, 2-heptanone/2-heptanol and 3methyl-2-pentanone/3-methyl-2-pentanol (Tab. V), indicating that the microflora present in Cantal cheese B had higher reducing activity than that present in Cantal cheese A. The presence of lower amounts of aldehydes, which are intermediary products resulting from a reduction of the corresponding primary alcohols during cheese ripening, confirms the elevated reducing conditions in Cantal cheese $B$, probably because of a different native microflora [9].

\subsection{Microstructure}

The confocal laser scanning micrograph pictures gathered in Figure 2 show the heterogeneous microstructure of Cantal cheese after $120 \mathrm{~d}$ of ripening, at different levels: in the centre (A, B, D) and under the surface $(C)$. From Figures $2 A$ and $2 B$, it is clearly seen that milk fat inclusions (red coloured), exist as (i) fat globules and (ii) free fat, (fat devoid of a fat globule membrane) which vary in size and shape, in the protein matrix as already described for different kinds of cheeses, such as Cheddar [32], Mozzarella [56], Camembert [51] and Emmental [50]. In Cantal cheese, it seems that little fat is present as intact fat globules in the protein network. It is likely that the natural milk fat globules, which have an average volumic diameter of $4 \mu \mathrm{m}$ in raw 
A

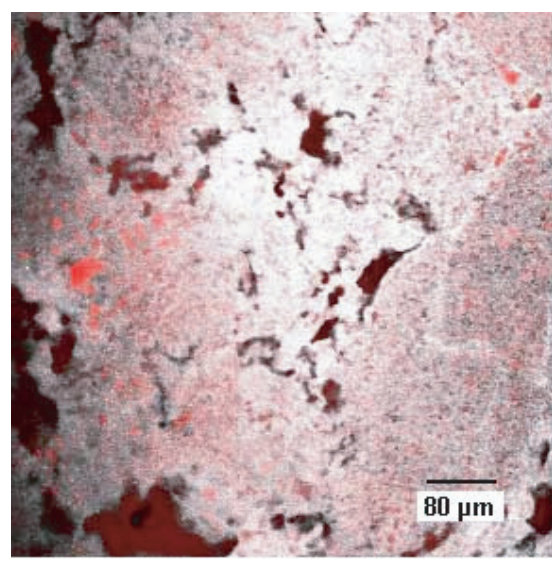

C

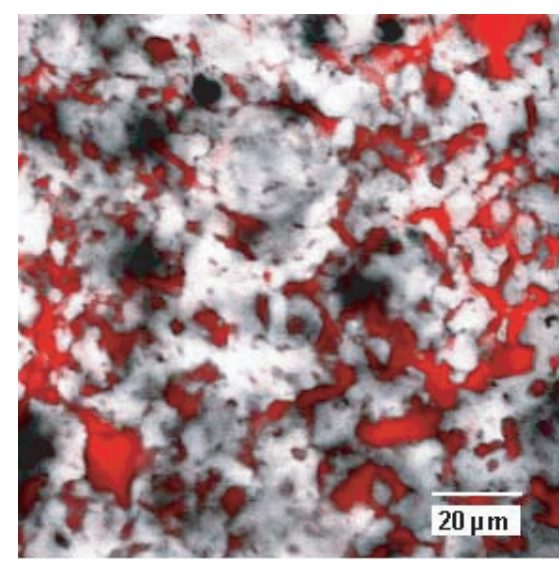

B

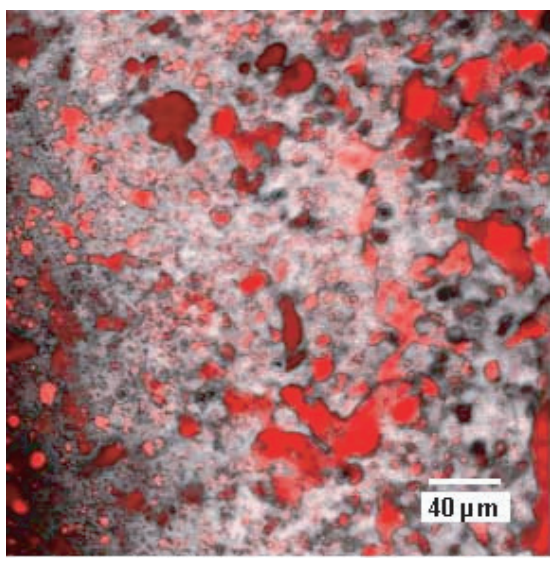

D

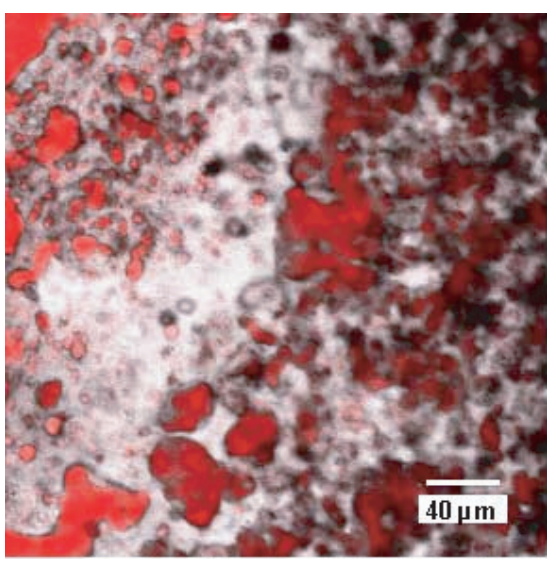

Figure 2. Confocal laser scanning micrographs of Cantal cheese corresponding to the microstructure in the centre (A, B, D) and under the surface (C). Fat appears in red, proteins in white.

milk, may have been disrupted by the thermal and mechanical treatments applied during the manufacture of Cantal cheese. Consequently, the fat which is not trapped in the protein network may easily be extracted from the cheese, as was seen during extraction of cheese juices. Moreover, these fat inclusions, which have a high ability to oil off, could play a role in the sensory and functional properties of Cantal cheese [38]. Such a disruption of the milk fat globule membrane, which is the physical barrier against enzymatic reaction, allows lipolysis and oxidation reactions [15] which occur at the triglyceride-matrix interfaces in the cheese during ripening of Cantal cheese. In parts A (lower scale) and D (higher scale) of Figure 2, a white zone dense in protein can be seen, which may correspond to a junction between two curd grains in the cheese matrix, as already characterised by CLSM in Emmental cheese (Lopez, personal communication). The part $\mathrm{C}$ of Figure 2 shows the microstructure of Cantal cheese, 
under the surface. Most of the fat seem to be free fat, located around protein grains. Such a fat structure under the crust fully agrees with the oily surface appearance which occurs when ripened Cantal cheese is heated.

\section{CONCLUSION}

The analysis carried out in this study allowed a precise characterisation of many aspects of two ripened Cantal cheeses issued from two different processes. In spite of many similarities with Cheddar, the obtained results on curd mineralisation demonstrate that the two varieties are not identical, probably because of the differences in the kinetics of acidification followed in the process of making these two varieties. Microbial enumerations, although they gave an interesting idea of the gross composition of the cheese flora (predominance of a mesophilic and thermophilic lactic acid bacteria flora accompanied by a very varied ripening flora including a significant yeast population) also showed the limitations of selectivity of the growth media used. Further studies with the use of modern biomolecular techniques are required to progress in further knowledge of the Cantal bacterial ecosystemi.e. not only an undoubted identification of the species but also a characterisation of their metabolic activity, notably in the proteolysis of the casein matrix and in the aroma biosynthesis, areas in which the results given here could be only very descriptive. The preliminary results on Cantal cheese fat microstructure shown for the first time in this study demonstrate how high the milk fat globules are sheared during the making process. Such shear stress made the cheese fat very accessible to the enzymes and for dissolving aroma compounds. Regarding another aspect, if the present study is the characterisation of ripened Cantal cheese, it should be very interesting to know how the different steps implemented from the cheese milk to the ripening conditions create the biochemical, physicochemical and microbial data reported here. That will be the subject of our next study.
Acknowledgements: We are indebted to the company $3 \mathrm{~A}$ and especially to its subsidiary LFO for their financial and technical support. We particularly want to express our gratitude to $\mathrm{M}$. Place and A. Vigier for their time implication and pertinent observations. The financial grant given to one of us by ANRT is also highly thanked.

\section{REFERENCES}

[1] AFNOR, Microbiologie des aliments. Méthode horizontale pour le dénombrement des microorganismes. Technique de comptage des colonies à $30^{\circ} \mathrm{C}$, Standard NF-V-08-011, 1978.

[2] AFNOR, Lait. Détermination des cendres, Standard NF-V-04-208, 1989.

[3] AFNOR, Microbiologie. Directives générales pour le dénombrement des coliformes. Méthode par comptage des colonies, Standard NF-V-08-015, 1991.

[4] AFNOR, Microbiologie des aliments. Méthode de routine pour le dénombrement des staphylocoques à coagulase positive par comptage des colonies à $37^{\circ} \mathrm{C}$. Partie 1 : technique avec confirmation des colonies, Standard NF-V-08-057-1, 1994.

[5] Arfi K., Leclercq-Perlat M.N., Baucher A., Tache R., Delettre J., Bonnarme P., Contribution of several cheese-ripening microbial association to aroma compound production, Lait 84 (2004) 435-447.

[6] Banks J.M., Williams A.G., The role of the nonstarter lactic acid bacteria in Cheddar cheese ripening, Int. J. Dairy Technol. 57 (2004) 145-152.

[7] Barlow I., Lloyd G.T., Ramshaw E.H., Miller A.J., Mc Cabe G.P., Mc Cabe L., Correlations and changes in flavour and chemical parameters of Cheddar cheese during maturation, Aust. J. Dairy Technol. 44 (1989) 7-18.

[8] Ben Lawlor J., Delahunty C.M., Sheehan J., Wilkinson M.G., Relationships between sensory attributes and the volatile compounds non-volatile and gross compositional consitutents of six blue-type cheeses, Int. Dairy J. 13 (2003) 481-494.

[9] Beuvier E., Buchin S., Raw milk cheeses in: Cheese: chemistry, physics and microbiology, vol. 1, 3rd edn., Elsevier, London, UK, 2004, pp. 319-345.

[10] Brulé G., Maubois J.L., Fauquant J., Étude de la teneur en éléments minéraux des produits obtenus lors de l'ultrafiltration du lait sur membrane, Lait 54 (1974) 600-615.

[11] Callon C., Millet L., Montel M.C., Diversity of lactic acid bacteria isolated from AOC Salers cheese, J. Dairy Res. 71 (2004) 231-244.

[12] CNIEL, L'économie laitière en chiffres, Paris, France, 2003. 
[13] CNIEL, L'économie laitière en chiffres, Paris, France, 2004.

[14] Cogan T.M., Hill C., Cheese starter cultures, in: Fox P.F. (Ed.), Cheese: chemistry, physics and microbiology, vol. 1, Chapman \& Hall, London, UK, 1993, pp. 193-255.

[15] Collins Y.F., McSweeney P.L.H., Wilkinson M.G., Lipolysis and catabolism of fatty acids in cheese in ripening, in: Cheese: chemistry, physics and microbiology, Vol. 1, 3rd edn., Elsevier, London, UK, 2004, pp. 373-389.

[16] Curioni P.M.G., Bosset J.O., Key odorants in various cheese types as determined by gas chromatography-olfactometry, Int. Dairy J. 12 (2002) 959-984.

[17] Curtin A.C., McSweeney P.L.H., Catabolism of aromatic amino acids in cheese-related bacteria: aminotransferase and decarboxylase activities, J. Dairy Res. 70 (2003) 249-252.

[18] De Noni I., Pellegrino L., Resmini P., Ferranti P., About presence of free phosphoserine in ripened cheese and in enzymatic hydrolysate of casein, Nahrung 41 (1997) 268-273.

[19] Denis C., Gueguen M., Henry E., Levert D., New media for the numeration of cheese surface bacteria, Lait 81 (2001) 365-379.

[20] Devoyod J.J., Millet L., La flore microbienne du fromage de Cantal fabriqué à partir de lait cru, Lait 538 (1974) 528-536.

[21] Duthoit F., Godon J.J., Montel M.C., Bacterial community dynamics during production of Registered Designation of Origin Salers cheese as evaluated by $16 \mathrm{~S}$ rRNA gene Single-Strand Conformation Polymorphism analysis, Appl. Environ. Microbiol. 69 (2003) 3840-3848.

[22] FIL-IDF, Détermination de la matière sèche (Méthode de référence), Standard 21B, Int. Dairy Fed., Brussels, Belgium, 1987.

[23] FIL-IDF, Détermination de la teneur en phosphore total, Standard 33C, Int. Dairy Fed., Brussels, Belgium, 1987.

[24] FIL-IDF, Fromages et fromages fondus Détermination de la teneur en matière grasse (Méthode gravimétrique), Standard 5B, Int. Dairy Fed., Brussels, Belgium, 1987.

[25] FIL-IDF, Lait et dérivés laitiers. Dénombrement des levures et moisissures, Standard 94B, Int. Dairy Fed., Brussels, Belgium, 1991.

[26] FIL-IDF, Détermination de la teneur en azote (Méthode Kjeldahl), Standard 20B, Int. Dairy Fed., Brussels, Belgium, 1993.

[27] FIL-IDF, Levains lactiques de cultures de bactéries lactiques. Norme de composition, Standard 149A, Int. Dairy Fed., Brussels, Belgium, 1997.

[28] FIL-IDF, Yogurt - Enumeration of characteristic microorganisms. Colony-count techni- que at $37^{\circ} \mathrm{C}$, Standard 117 , Int. Dairy Fed., Brussels, Belgium, 2003.

[29] Fox P.F., McSweeney P.L.H., Lynch C.M., Significance of non-starter lactic acid bacteria in cheddar cheese, Aust. J. Dairy Technol. 53 (1998) 83-89.

[30] Gagnaire V., Mollé D., Herrouin M., Léonil J., Peptides identified during Emmental cheese ripening: origin and proteolytic systems involved, J. Agric. Food Chem. 49 (2001) 4402-4413.

[31] Gaucheron F., Le Graët Y., Piot M., Boyaval E., Determination of anions of milk by ion chromatography, Lait 76 (1996) 433-443.

[32] Guinee T.P., Auty M.A.E., Fenelon M.A., The effect of fat content on the rheology, microstructure and heat-induced functional characteristics of Cheddar cheese, Int. Dairy J. 10 (2000) 277-288.

[33] Hassan A., Johnson M.E., Lucey J.A., Changes in the proportions of soluble and insoluble calcium during the ripening of Cheddar cheese, J. Dairy Sci. 87 (2004) 854-862.

[34] Imhof R., Bosset J.O., Relationships between micro-organisms and formation of aroma compounds in fermented dairy products Review, Z. Lebensm.-Unters.-Forsch. 198 (1994) 267-276.

[35] Imhof R., Glättli H., Bosset J.O., Volatile organic compounds produced by thermophilic and mesophilic single strain dairy starter cultures, Lebensm. Wiss. Technol. 28 (1995) $78-86$.

[36] ISO, Microbiology of food and animal feeding stuffs. Horizontal method for the enumeration of presumptive Escherichia coli; Part 2: Colony-count technique at $44{ }^{\circ} \mathrm{C}$ using 5-bromo-4-chloro-3-indolyl- $\beta$-D-glucoronic acid, Standard ISO 16649-2, 1999.

[37] Isolini D., Grand M., Glättli H., Selektivmedien zum Nachweis von obligat und fakultativ heterofermentativen Laktobazillen, Schweiz. Milchw. Forsch.19 (1990) 57-59.

[38] Jaros D., Petrag J., Rohm H., Ulberth F., Milk fat composition affects mechanical and rheological properties of processed cheese, Appl. Rheol. 11 (2001) 19-25.

[39] Keen A.R., Walker N.J., Peberdy M.F., The formation of 2-butanone and 2-butanol in Cheddar cheese, J. Dairy Res. 41 (1974) 249-257.

[40] Kuchroo C.N., Fox P.F., Soluble nitrogen in Cheddar cheese: comparison of extraction procedures, Milchwissenschaft 37 (1982) 331-335.

[41] Laht T.M., Kask S., Elias P., Adamberg K., Paalme T., Role of arginine in the development of secondary microflora in Swiss-type cheese, Int. Dairy J. 12 (2002) 831-840.

[42] Lucey J.A., Gorry C., Fox P.F., Changes in the acid-base buffering curves during the 
ripening of Emmental cheese, Milchwissenschaft 48 (1993) 183-186.

[43] Maarse H., Visscher C.A., Willemsens L.C., Nijssen L.M., Boelens M.H., in: Volatile Compounds in Food: qualitative and quantitative data, TNO Nutrition and Food Research, Zeist, The Netherlands, 1994.

[44] Madec M.N., Rouault A., Maubois J.L., Thierry A., Milieu sélectif et procédé pour le dénombrement des bactéries propioniques, Patent Application FR 2700778, 1994.

[45] Marsili R., Monitoring chemical changes in Cheddar cheese during aging by HPLC and GC techniques, J. Dairy Sci. 68 (1985) 31553161.

[46] Martin B., Verdier-Metz I., Cornu A., Pradel P., Hulin S., Buchin S., Dupont D., Lamaison J.L., Carnat A.P., Berdagué J.L., Coulon J.B., Do terpenes influence the flavour of cheeses? II. Cantal cheese, Caseus Int. 3 (2002) 25-27.

[47] McSweeney P.L.H., Sousa M.J., Biochemical pathways for the production of flavour compounds in cheeses during ripening: a review, Lait 80 (2000) 293-324.

[48] Mead G.C., Adams B.W., A selective medium for the rapid isolation of Pseudomonas associated with poultry meat spoilage, Br. Poult. Sci. 18 (1977) 661-670.

[49] Mermet J.M., Intérêt et principe de la spectrométrie atomique dans le dosage des minéraux, in: Gaucheron F. (Ed.), Minéraux et produits laitiers, Tec \& Doc Lavoisier, Paris, France, 2004, pp. 815-846.

[50] Michalski M.C., Gassi J.Y., Famelart M.H., Leconte N., Camier B., Michel F., Briard V., The size of native milk fat globules affects physico-chemical and sensory properties of Camembert cheese, Lait 83 (2003) 131-143.

[51] Michalski M.C., Camier B., Briard V., Leconte N., Gassi J.Y., Goudedranche H., Michel F., Fauquant J., The size of native milk fat globules affects physico-chemical and functional properties of Emmental cheese, Lait 84 (2004) 343-358.

[52] Millet L., Melcion D., Devoyod J.J., La flore microbienne du fromage de Cantal fabriqué à partir de lait cru. I - Techniques d'études et résultats préliminaires, Lait 537(1974)397-407.

[53] Millet L., Melcion D., Devoyod J.J., La flore microbienne du fromage de Cantal fabriqué à partir de lait cru. III - Rôle des levures dans la maturation de la "tome", Lait 54 (1974) 616-627.

[54] République Française, Décret du 29 décembre 1986 relatif à l'appellation d'origine "Cantal" ou "Fourme de Cantal", J.O.R.F. du 1 er janvier 1987.

[55] Robinson R.K., Wilbey R.A., Importance of cheese as a food, in: Scott R. (Ed.), Cheesemaking Practice, Aspen, UK, 1998, p. 11.
[56] Rowney M.K., Roupas P., Hickey M.W., Everett D.W., The effect of compression stretching and cooking temperature on free oil formation in Mozzarella curd, J. Dairy Sci. 86 (2003) 449-456.

[57] Roy D., Pitre M., Blanchette L., Savoie L., Belanger G., Ward P., Maubois J.L., Monitoring proteolysis and cheese juice composition during ripening of Cheddar cheese made from microfiltered milk, Lait 77 (1997) 521-541.

[58] Saboya L.V., Goudedranche H., Maubois J.L., Lerayer A.L.S., Lortal S., Impact of broken cells of lactococci or propionibacteria on the ripening of Saint-Paulin UF-cheeses: extent of proteolysis and GC-MS profiles, Lait 81 (2001) 699-713.

[59] Salvat-Brunaud D., Maubois J.L., Le Graët Y., Maillard M.B., Corre C., Thierry A., Extraction et analyse de la phase aqueuse de l'Emmental à quatre stades d'affinage, Lait 75 (1995) 239-249.

[60] Shakeel-ur-rehman, Banks J.M., McSweeney P.L.H., Fox P.F., Effect of ripening temperature on the growth and significance of nonstarter lactic acid bacteria in Cheddar cheese made from raw or pasteurised milk, Int. Dairy J. 10 (2000) 45-53.

[61] Thierry A., Maillard M.B., Le Quéré J.L., Dynamic headspace analysis of Emmental aqueous phase as a method to quantify changes in volatile flavour compounds during ripening, Int. Dairy J. 9 (1999) 453-463.

[62] Thierry A., Salvat-Brunaud D., Madec M.N., Michel F., Maubois J.L., Affinage de l'Emmental : dynamique des populations bactériennes et évolution de la composition de la phase aqueuse, Lait 78 (1998) 521-542.

[63] Urbach G., Relations between cheese flavour and chemical composition, Int. Dairy J. 3 (1993) 389-422.

[64] Urbach G., Contribution of lactic acid bacteria to flavour compound formation in dairy products, Int. Dairy J. 5 (1995) 877-903.

[65] Verdier-Metz I., Martin B., Hulin S., Ferlay A., Pradel P., Coulon J.B., Combined influence of cow diet and pasteurisation of the milk on sensory properties of French PDO Cantal cheese, Poster, IDF World Congress, Paris, France, 2002.

[66] White D.G., Matos J.S., Harmon R.J., Langlois B.E., A comparison of six selective media for the enumeration and isolation of staphylococci, J. Food Prot. 51 (1988) 685-690.

[67] Yang W.T., Min D.B., Dynamic headspace analyses of volatile compounds of Cheddar and Swiss Cheese during ripening, J. Food Sci. 59 (1994) 1309-1312. 